\title{
RIKEN NATURAL RADIOCARBON MEASUREMENTS III
}

\author{
FUMIO YAMASAKI, TATSUJI HAMADA and \\ CHIKAKO FUJIYAMA
}

Institute of Physical and Chemical Research (RIKEN)

Komagome, Bunkyo-ku, Tokyo, Japan

The $\mathrm{C}^{14}$ dates given below are a continuation of the work presented in our previous list (RIKEN II), and have been obtained by counting $\mathrm{CO}_{2}$ at ca. $2 \mathrm{~atm}$ pressure in a $2.7 \mathrm{~L}$ stainless steel counter. Results obtained during 1966 are described.

Shell samples were treated with $1 \% \mathrm{HCl}$ to remove the outer $10 \%$. Calcareous deposits on the surface, when observed, were removed by mechanical means.

Dates have been calculated on the basis of the $\mathrm{C}^{14}$ half-life of 5568 yr and $95 \%$ of NBS oxalic acid as modern standard. No correction was applied even for fresh water shell samples.

\section{SAMPLE DESCRIPTIONS}

\section{Daisen series}

I. GEOLOGIC SAMPLES

Wood found at various sites around Mt. Daisen volcano. Coll. 1964-65 and subm. by T. Kimachi, Yonago Kita High School.

$$
2650 \pm 120
$$

\section{N-262. Hojogawa}

700 B.c.

Wood from Shima, Hojo-cho, Tohaku-gun, Tottori pref., NE side

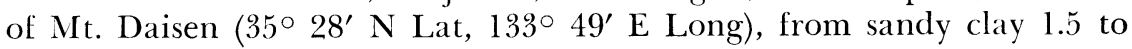
$2.0 \mathrm{~m}$ beneath surface, associated with ancient pottery.

\section{N-263. Ohsuzume}

$18,400 \pm 400$

Wood from Ohsuzume, Nawa-cho, Saihaku-gun, Tottori pref., NW side of Mt. Daisen (35 $30^{\prime} \mathrm{N}$ Lat, $133^{\circ} 28^{\prime} \mathrm{E}$ Long), from lacustrine clay $0.2 \mathrm{~m}$ thick, in pyroclastic flow, $8 \mathrm{~m}$ below surface.

\section{N-219. Nakabori-sawa}

$$
2760 \pm 120
$$

810 B.c.

Wood from Nakabori-sawa, Azusagawa-mura, Minami-azumi-gun, Nagano pref. (36 $14^{\prime} \mathrm{N}$ Lat, $137^{\circ} 37^{\prime} \mathrm{E}$ Long), from mudflow $7 \mathrm{~m}$ thick, within pyroclastic flow of Mt. Yakedake volcano. Coll. 1964 by S. Kawachi, Hokkaido Univ.; subm. by M. Oishi, Natl. Research Center for Disaster Protection. Comment (M.O.): date indicates one of quiescent periods of volcano.

\section{Northern Ungava series}

Marine pelecypod shells from various sites in Northern Ungava, Quebec, Canada. Coll. 1962 and subm. by Barry Matthews, McGill Univ. 
Samples provide data for construction of glacio-isostatic-uplift curve (Matthews, 1962; 1966).

\section{N-281. Erik Cove}

$7030 \pm 150$

Hiatella arctica from Erik Cove, Northern Ungava $\left(62^{\circ} 31^{\prime} \mathrm{N}\right.$ Lat, $77^{\circ} 26^{\prime}$ W Long). From pit $154 \mathrm{ft}$ above sealevel, $2 \mathrm{ft}$ deep, in side of 221-ft marine terrace, at mouth of Ruisseau des Mollusques. Contained 2 Boreal-Lusitanian species of foram. viz. Miliammina fusca and Triloculina trigonula. Comment (B.M.): date considerably more than anticipated; suggests deposits were laid down in offshore zone as suggested by presence of Pecten islandicus.

\section{N-282. Sugluk Inlet 1}

$5220 \pm 130$

3270 в.c.

Hiatella arctica from Sugluk Inlet, Northern Ungava $\left(62^{\circ} 11^{\prime} \mathrm{N}\right.$ Lat, $75^{\circ} 37^{\prime} \mathrm{W}$ Long). From 20-ft marine terrace (Hemythyris beach), at mouth of Ruisseau de l'Airelle. Contained pelecypods: Lyonsia hyalina and Mya arenaria; foram.: Miliammina fusca, Angulogerina angulosa.

\section{N-284. Sugluk Inlet 2}

$5230 \pm 130$

Mya truncata from Sugluk Inlet, Arctic Ungava $\left(62^{\circ} 10^{\prime} \mathrm{N}\right.$ Lat, $75^{\circ} 58^{\prime} \mathrm{W}$ Long). From $41 \mathrm{ft}$ alt in $47 \mathrm{ft}$ marine terrace at mouth of Rivière Tourbe. Correlated with Upper Gemma beach at Deception Bay, $30 \mathrm{mi}$ E. Contained Yoldia myalis, Balanus hameri, Plactopecten magellanicus and Mya arenaria.

Comment for N-282 and N-284 (B.M.): despite difference of $31 \mathrm{ft}$ in alt and differing percentages of various mollusk species, both samples appear to have formed about same time but probably in different depths of water. Comparative richness of marine fauna in both samples suggests fauna was living during Hudson Strait's "marine optimum." Date of N-284 gives age for Upper Aporrhais Beach (53 ft strandline).

\section{N-283. Deception Bay}

$6980 \pm 150$

5030 B.c.

Hiatella arctica from Deception Bay, Northern Ungava $\left(62^{\circ} 7^{\prime} \mathrm{N}\right.$ Lat, $74^{\circ} 38^{\prime} \mathrm{W}$ Long). From surface of postglacial marine sediment, alt $275 \mathrm{ft}$, near upper marine limit on S side of Rivière Renard-Noire. Comment (B.M.): shell from $297 \mathrm{ft}$ yielded $6970 \pm 150 \mathrm{yr}$ (NPL-85, NPL IV). Date suggests Elphidium Beach strandline, $345 \mathrm{ft}$ alt, was formed ca. 7000 yr ago.

\section{N-285. Kugluk Cove}

$6070 \pm 140$

Mya arenaria and Mya truncata from Kugluk Cove, Northern Ungava (62 $10^{\prime} \mathrm{N}$ Lat, $75^{\circ} 58^{\prime} \mathrm{W}$ Long). From 70 -ft marine terrace, valley of Rivière Kugluk. Contained foram. Miliammina fusca. Comment (B.M.): date gives possible age of Upper Tunit Beach strandline $(100 \mathrm{ft}$ alt). 
II. ARCHAEOLOGIC SAMPLES

\section{Nishitsukigaoka series}

$$
\text { A. Japan }
$$

Charcoal found on floor of two dwelling pits at Nishitsukigaoka, Nemuro city, Hokkaido (43 $19^{\prime} \mathrm{N}$ Lat, $145^{\circ} 34^{\prime}$ E Long). Excavation 1963 by I. Yawata, Tokyo Univ. of Education. Pottery was of Satsumon type. Coll. 1963 by T. Iwasaki; subm. by I. Yawata through N. Watanabe.

\section{N-264. Nishitsukigaoka 1}

Charcoal from Dwelling Pit 120.

\section{N-265. Nishitsukigaoka 2}

Charcoal from Dwelling Pit 7.

\section{N-226. Tosamporo}

Charred timber found $10 \mathrm{~cm}$ above floor of Dwelling Pit 30 at Tosamporo, Nemuro city, Hokkaido ( $43^{\circ} 23^{\prime} \mathrm{N}$ Lat, $145^{\circ} 45^{\prime} \mathrm{E}$ Long). Excavated 1964 by I. Yawata, Tokyo Univ. of Education. Associated with Oshigata-mon pottery of Earliest Jomon period. Coll. 1964 by T. Irasaki; subm. by I. Yawata through N. Watanabe. Comment (I.Y.): date is much younger than expectation.

\section{N-267. Mawatari}

Charred timber, Quercus serrata (id. by S. Watari) from ceramic kiln 6 at Mukaino, Mawatari, Katsuta city, Ibaragi pref. $\left(36^{\circ} 24^{\prime} \mathrm{N}\right.$ Lat, $140^{\circ} 34^{\prime}$ E Long). Excavated 1965 by H. Otsuka, Meiji Univ. Associated with Onitaka type of Haji pottery. An adjacent kiln yielded fragments of haniwa figures. Coll. 1965 and subm. by H. Otsuka through N. Watanabe.

\section{Sobata series}

Shell mound of Jomon period, at Sobata, Iwakoso, Udo city, Kumamoto pref. (32॰ $41^{\prime} \mathrm{N}$ Lat, $130^{\circ} 41^{\prime} \mathrm{E}$ Long). Excavated 1959 by $\mathrm{T}$. Esaka, Keio Univ. Coll. 1959 and subm. by N. Watanabe.

\section{N-268. Sobata 1}

$5190 \pm 130$

3240 B.c.

Marine shell (Anadara sp.) from shell layer at $\mathrm{C}$ trench associated with Sobata type pottery of Earliest Jomon period.

\section{N-269. Sobata 2}

$3300 \pm 125$

Marine shell (Ostrea sp.) from shell layer at loc. AT 7 associated with Kanegasaki type pottery of Late Jomon period. 
N-271. Sannomiya

Charcoal found in soil layer $1 \mathrm{~m}$ below ground surface, $25 \mathrm{~m}$ outside of Dwelling Pit 202 at Shimoyado, Sannomiya, Isehara-machi, Naka-gun,

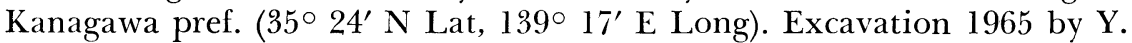
Koide, Kokugakuin Univ. Pottery associated with dwelling pit was of Maenocho type of Yayoi period. Coll. 1965 and subm. by Y. Koide through N. Watanabe. Comment (Y.K.): date is too old to be assigned to Maenocho type pottery. Possibly sample is contemporary to either of two stone structures of Late Jomon period located at 1 and $5 \mathrm{~m}$ distance from it respectively.

\section{N-180. Kohara}

$2970 \pm 120$

1020 B.C.

Fresh water pelecypod shell (Corbicula japonica) from Kohara shell mound, Site A, Kozaki-machi, Katori-gun, Chiba pref. (35 $5 \mathrm{l}^{\prime} \mathrm{N}$ Lat, $140^{\circ} 23^{\prime}$ E Long). Shell layer, 10 to $25 \mathrm{~cm}$ thick, is on dark soil 15 to 20 $\mathrm{cm}$ thick overlying loam and accompanied by Late Jomon pottery of Angyo I type (Nishimura, 1956). Coll. and subm. 1965 by M. Nishimura, Waseda Univ.

\section{N-181. Ohkura}

$3120 \pm 120$

1170 в.C.

Marine pelecypod shell (Meretrix lusoria) from Ohkura shell mound, Sawara city, Katori-gun, Chiba pref. (35 $53^{\prime} \mathrm{N}$ Lat, $140^{\circ} 32^{\prime} \mathrm{E}$ Long). Shell layer, up to $2 \mathrm{~m}$ thick, is on dark soil 20 to $40 \mathrm{~cm}$ thick overlying loam and accompanied by Late Jomon pottery of Kasori B-I and B-II type, which are believed preceding pottery of Angyo type (Nishimura, 1954; Nishimura and Kaneko, 1954). Coll. and subm. 1965 by M. Nishimura.

\section{Atamadai shell mound series}

Marine pelecypod and gastropod shell from Atamadai shell mound, Gogouchi, Omigawa-machi, Katori-gun, Chiba pref. (35 $41^{\prime} \mathrm{N}$ Lat, $140^{\circ}$ $37^{\prime} \mathrm{E}$ Long). Shell layer, up to $2 \mathrm{~m}$ thick, is on dark soil and accompanied by Middle Jomon pottery of Atamadai I and II and Kasori E type (Nishimura, 1957). Coll. and subm. 1965 by M. Nishimura.

N-182-1. Atamadai 1

Meretrix lusoria.

\section{N-182-2. Atamadai 2}

Meretrix lusoria.
$4400 \pm 110$

2450 B.C.

$4480 \pm 110$

2530 B.C.

General Comment: both samples are from same source. 


\section{Ta shell mound series}

Fresh water and marine pelecypod shell from Ta shell mound, Towadamura, Tsukuba-gun, Ibaragi pref. $\left(36^{\circ} 0^{\prime} \mathrm{N}\right.$ Lat, $140^{\circ} 2^{\prime} \mathrm{E}$ Long). Dwelling pit dug in loam and accompanied by Early Jomon pottery of Sekiyama type which is believed preceding pottery of Uebo type. Shell layer, 40 to $50 \mathrm{~cm}$ thick, is on loam. Coll. and subm. 1965 by M. Nishimura.

\section{N-191-1. Ta 1}

$5640 \pm 150$

Meretrix lusoria.

N-191-2. Ta 2

3690 B.C.

Corbicula japonica.

$5630 \pm 140$

3680 B.c.

\section{Uchinoyama shell mound series}

Fresh water and marine pelecypod shell from Uchinoyama shell mound, Sashima-cho, Sashima-gun, Ibaragi pref. $\left(36^{\circ} 5^{\prime} \mathrm{N}\right.$ Lat, $139^{\circ} 55^{\prime}$ E Long). Shell layer, up to $50 \mathrm{~cm}$ thick, is in between dark soil 1 to $1.2 \mathrm{~m}$ thick. According to stylistic chronology of pottery, it is believed preceding Uebo type (Nishimura, 1958). Coll. and subm. 1965 by M. Nishimura.

N-200-1. Uchinoyama 1

Corbicula japonica.

\section{N-200-2. Uchinoyama 2}

Meretrix lusoria.

\section{N-241. Uebo}

Carbon in pottery matrix of potsherd from Uebo shell mound, Kozaki-machi, Katori-gun, Chiba pref. ( $35^{\circ} 52^{\prime} \mathrm{N}$ Lat, $140^{\circ} 23^{\prime} \mathrm{E}$ Long). More than $1 \%$ by weight of carbon is contained in matrix, which is considered to come from plant material added in clay during processing of pots. Pottery is of Early Jomon, Uebo type. Coll. and subm. 1965 by M. Nishimura. Comment: shell from same shell mound yielded $5340 \pm$ 150 (N-178, RIKEN II).

\section{N-242. Ishigami}

Carbon in pottery matrix of potsherd from Ishigami remain, Moritamura, Nishi-tsugaru-gun, Aomori pref. ( $40^{\circ} 47^{\prime} \mathrm{N}$ Lat, $140^{\circ} 19^{\prime} \mathrm{E}$ Long). Pottery is of Early Jomon, Ento-kaso B type (Nishimura, 1951). Coll. and subm. 1965 by M. Nishimura. 


\section{Yaeyama Islands series}

Marine shell samples from various shell mounds in Yaeyama Islands, southern Okinawa (Nishimura, Tamaguchi, Okawa and Hamana, 1959). Coll. and subm. 1966 by M. Nishimura.

\section{N-258. Nakama}

$1210 \pm 110$

Pelecypod shell (Glyphaea vitrefacta) from Nakama No. 1 shell mound, Iriomote Is. (24 $16^{\prime} \mathrm{N}$ Lat, $123^{\circ} 54^{\prime} \mathrm{E}$ Long). Shell layer, 1 to $1.5 \mathrm{~m}$ thick, overlain by soil $30 \mathrm{~cm}$ thick. No potsherd was found.

\section{N.259. Shimotabaru}

$3800 \pm 130$

Pelecypod shell (Geloina papua) from Shimotabaru shell mound, Hateruma Is. (24 $3^{\prime} \mathrm{N}$ Lat, $123^{\circ} 48^{\prime} \mathrm{E}$ Long). Shell layer, 50 to $80 \mathrm{~cm}$ thick, overlain by soil 20 to $30 \mathrm{~cm}$ thick. Few potsherds were found.

\section{N-260. Pinishi}

A.D. 1600

$350 \pm 110$

Pelecypod shell (Geloina papua) from shell mound in Pinishi Is. (24 $30^{\prime} \mathrm{N}$ Lat, $123 \circ 42^{\prime} \mathrm{E}$ Long). Shell layer, 1 to $1.5 \mathrm{~m}$ thick, is on bed rock, overlain by soil 30 to $40 \mathrm{~cm}$ thick, and accompanied by abundant potsherds including Chinese green-glazed porcelain.

\section{N-261. Yamabaru}

$600 \pm 100$

Pelecypod shell (Tricacta crocea) from Yamabaru shell mound, SE of Ishigaki city, Ishigaki Is. (24 $20^{\prime} \mathrm{N}$ Lat, $124^{\circ} 10^{\prime} \mathrm{E}$ Long). Shell layer, 50 to $100 \mathrm{~cm}$ thick, is overlain by soil 30 to $40 \mathrm{~cm}$ thick and accompanied by potsherds including green-glazed porcelain and iron ware.

\section{Itanki Peshibokke series}

Uncharred animal bone (Canis sp.) from ancient remain of Itanki Peshibokke, Muroran city, Hokkaido $\left(42^{\circ} 18^{\prime} \mathrm{N}\right.$ Lat, $140^{\circ} 54^{\prime} \mathrm{E}$ Long). Coll. and subm. 1965 by N. Shimoda, Muroran Univ. of Technology.

\section{N-243. Itanki Peshibokke 1}

$2010 \pm 120$

Bone from $70 \mathrm{~cm}$ below surface.

\section{N-244. Itanki Peshibokke 2}

60 B.C.

Bone from $80 \mathrm{~cm}$ below surface.

\section{N-245. Itanki Peshibokke 3}

Bone from $90 \mathrm{~cm}$ below surface.

Comment (N.S.): dates serve to test possibility of dating bones by measurements of their manganese content. 


\section{B. Korea}

\section{Dabang-ri series}

Charcoal samples from shell mound of Iron age on $85 \mathrm{~m}$ above sealevel hill at Dabang-ri, Ryangsan-eup, Kyungsangnamdo, Korea $\left(35^{\circ} 20^{\prime}\right.$ $\mathrm{N}$ Lat, $129^{\circ} 2^{\prime} \mathrm{E}$ Long). Three layers containing shell, down to $2 \mathrm{~m}$ below surface, are distinguished, numbered I to III in clescending order. Coll. 1965 by Won-Yong Kim, Seoul Natl. Univ.; subm. by S. Izumi, Univ. of Tokyo.

\section{N-236. Dabang-ri 1}

$1750 \pm 120$

Charcoal from Layer I, Site S 1.

\section{N-237. Dabang-ri 2}

$1520 \pm \mathbf{1 5 0}$

Charcoal from Layer II, Site S 6. Comment: larger error is due to shortage of sample.

\section{N-238. Dabang-ri 3}

$1750 \pm 120$

Charcoal from bottom of Layer III, Site S 6 .

N-239. Dabang-ri 4

$1840 \pm 120$

Charcoal from Layer III, Site N 2, $125 \mathrm{~cm}$ below surface.

\section{N-240. Pungnam-ri}

$$
1720 \pm 110
$$

Charcoal from ancient dwelling site in fortress of Early Samkook period at Pungnam-ri, Sungdong-ku, Seoul, Korea $\left(37^{\circ} 35^{\prime} \mathrm{N}\right.$ Lat, $127^{\circ}$ $7^{\prime}$ E Long). Sample was on floor of site, ca. $1.4 \mathrm{~m}$ below surface, overlain by sand and clay layer 40 to $140 \mathrm{~cm}$ thick containing potsherds.

\section{East Africa}

\section{N-256. Kilwa Kisiwani, Tanzania}

$$
790 \pm 110
$$

Charcoal associated with lime kiln at Kilwa Kisiwani, Tanzania ( $8^{\circ} 57^{\prime} \mathrm{S}$ Lat, $39^{\circ} 31^{\prime} \mathrm{E}$ Long), $3.2 \mathrm{~m}$ below present ground level, contemporary with first introduction of coins and probably with arrival of "Shirazi" (Chittick, 1965). Coll. 1965 by R. C. Soper; subm. by H. N. Chittick, Brit. Inst. Hist. and Archaeol. E. Africa.

$$
1080 \pm 110
$$

\section{N-257. Gonja Maore, Tanzania}

\section{A.D. 870}

Charcoal from near base of mound of dung and domestic rubbish at Gonja Maore, Pare District, Tanzania (4० $16^{\prime} \mathrm{S}$ Lat, $38^{\circ} 2^{\prime} \mathrm{E}$ Long), probably dating from first Iron age of area (Fosbrooke, 1955). Coll. 1965 by R. C. Soper; subm. by H. N. Chittick. 


\section{Ivuna salt pans series}

An ancient Iron age sequence is found in ancient salt working dumps on edge of Ivuna pans, $110 \mathrm{mi}$ SW of Mbeya, southern Tanzania ( $8^{\circ} 26^{\prime} \mathrm{S}$ Lat, $32^{\circ} 29^{\prime} \mathrm{E}$ Long). Excavations were carried out in these dumps. Coll. 1966 by B. M. Fagan and J. E. Yellen; subm. by B. M. Fagan, Brit. Inst. Hist. and Archaeol. E. Africa.

\section{N-272. Ivuna salt pans, IV/2}

Charcoal from Trench III, $0.9 \mathrm{~m}$ below surface.

N-273. Ivuna salt pans, IV/4(5)

$575 \pm 110$

Charcoal from Trench I, $2.4 \mathrm{~m}$ below surface.

\section{N-274. Ivuna salt pans, IV $/ 6$}

$695 \pm 110$

Charcoal from Trench I, $3.6 \mathrm{~m}$ below surface.

\section{N-275. Ivuna salt pans, IV/8}

Charcoal from Trench I/E, $5.4 \mathrm{~m}$ below surface.

Comment (B.M.F.): lower level dates seem most acceptable since they are associated with pottery of earlier Iron age type. Two upper dates may be earlier than they should be, in view of oral historical evidence that salt pans were in use as late as A.D. 1900.

Date Lists:

\section{REFERENCES}

NPL IV Callow, Baker and Hassall, 1966

RIKEN II Yamasaki, Hamada and Fujiyama, 1966

Chittick, H. N., 1965, The "Shirazi" Colonization of East Africa; Jour. African Hist., v. 6 , no. 3 .

Fosbrooke, H. A., 1955, Early Iron Age sites in Tanganyika related to traditional history; Pan African Congress of Prehistory, 3rd, 1955, Proc., p.318-325.

Matthews, B., 1962, Glacial and post-glacial geomorphology of the Sugluk-wolstenholme area, Northern Ungava: McGill Sub-arctic Research Papers, no. 12, p. 17-46.

Matthews, B., 1966, Radiocarbon dated postglacial land uplift in Northern Ungava, Quebec, Canada; Nature, v. 211, p. 1164-1166.

Nishimura, M., 1951, Sites about the village of Morita, Nishitsugaru-gun, Aomori prefecture; Archaeologia Japonica, Annual Rept. of Japanese Archaeol. Assoc., no. 4.

Shell mound of Ohkura, Katori-gun, Chiba prefecture; Archaeologia Japonica, Annual Rept. of Japanese Archaeol. Assoc., no. 7.

1956, Shell mound of Kohara, Katori-gun, Chiba prefecture; Archaeologia Japonica, Annual Rept. of Japanese Archaeol. Assoc., no. 9.

1957, Shell mound of Atamadai, Katori-gun, Chiba prefecture; Archaeologia Japonica, Annual Rept. of Japanese Archaeol. Assoc., no. 10.

1958, Shell mound of Uchinoyama, Sashima-gun, Ibaragi prefecture; Archaeologia Japonica, Annual Rept. of Japanese Archaeol. Assoc., no. 11.

Nishimura, M., and Kaneko, H., 1954, The southern shell mound of Ohkura, Katorigun, Chiba prefecture: Kodai, no. 21, 22.

Nishimura, M., Tamaguchi, T., Okawa, K., and Hamana, A., 1959, Archaeology of Yaeyama: Yaeyama, ed. by H. Takiguchi, Azckura Pub. Co., Tokvo. 